NBER WORKING PAPER SERIES

\title{
THE EFFEC'IS OF PENSIONS AND EARNINGS \\ ON RETIREMENT: A REVIEW ESSAY
}

\author{
Olivia S. Mitchell \\ Gary S. Fields \\ Working Paper No. 772 \\ NATIONAL BUREAU OF ECONOMIC RESEARCH \\ 1050 Massachusetts Avenue \\ Cambridge MA 02138 \\ September 1981
}

\begin{abstract}
Respectively, Assistant Professor of Labor Economics and Associate Professor of Labor Economics and Economics, New York State School of Industrial and Iabor Relations, Cornell University. Both authors are equally responsible for the contents of this paper; first mention is determined randomly. Research support from the Department of Labor and Cornell University is gratefully acknowledged. The research reported here is part of the NBER's research program in Labor Studies and Pensions. The views expressed are those of the authors and do not represent the policy or practice of these institutions. Helpful comments were provided by Gloria Bazzoli, Vincent Crawford, Alan Gustman and Robert Smith.
\end{abstract}


The Effects of Pensions and Earnings

on Retirement: A Review Essay

\section{ABSTRACT}

Does retirement behavior react predictably to economic incentives?

Evidence on this question would be useful to policy makers responsible

for work and retirement programs affecting the elderly. This paper reviews

the lessons and limitations of recent economics literature on pensions, earnings, and retirement. ${ }^{1}$ Section I develops the life cycle context for analyzing this problem. Theoretical literature is examined in section II, followed by a review of the empirical literature in section III. Conclusions appear at the end of each section.

${ }^{1}$ Additional determinants of retirement which we do not review in this paper are health, changes in the valuation of leisure time as workers age, labor supply interactions between household members, and the impact of inflation as well as other types of uncertainty. For a review of the literature on these additional determinants, see Clark and Spengler, and Clark.

Olivia S. Mitchell

National Bureau of Economic

Research

1050 Massachusetts Avenue

Cambridge, MA 02138

(617) 868-3911
Gary S. Fields

New York State School of

Industrial and Labor Relations

Corne11 University

Ithaca, New York 14853 


\section{RETIREMENT IN A LIFE CYCLE CONTEXT}

\section{A. The Problem}

This review of existing theoretical and empirical models of the effects of pensions and earnings on retirement is guided by life cycle theory. The individual's problem is to choose the optimal amount of work to do in each of the remaining T years of life. "Optimal" is defined as the labor supply path that maximizes lifetime utility, a function of consumption and leisure. An individual's income possibilities are constrained by his lifetime earning capacity and his pension opportunities (including both employer-provided benefits and Social Security payments). Thus, a life cycle framework leads immediately to a structure in which the lifetime labor supply path $(\vec{H})$ is a function of the lifetime streams of earnings ( $(\vec{E})$, pensions $(\vec{P})$. and other pertinent explanatory variables $(\vec{X})$ :

(1) $\vec{H}=L(\vec{E}, \overrightarrow{\mathrm{P}}, \overrightarrow{\mathrm{X}})$. Various aspects of the labor supply vector $\overrightarrow{\mathrm{H}}$ may be selected for analysis: whether or how much the individual is working as of some age, whether or how much he is working as of some calendar date, whether he retires early or not, or his age of retirement. Regardless of which of these measures is used as the dependent variable, to be true to life cycle theory, the independent variables in equation (1) must be expressed as streams and not just in terms of their current leveis. Models without this feature are fundamentally flawed. 
Another evaluation standard used in this review is sensitivity of the various models to essential institutional features of pensions. One such feature is that pensions, unlike most other economic assets, have a contingency provisions: to receive a pension, one typically must not work. ${ }^{l}$ Secondly, pension benefits per year typically increase if retirement is deferred. ${ }^{2}$ And thirdly, whereas some pension plans are actuarially neutral, ${ }^{3}$ most are not. 4 Models which neglect the contingency provision, the increase in pensions if reitrement is delayed the possibility of actuarial nonneutrality run the risk of reaching conclusions of quite limited applicability.

IEmployers usually require that the worker cease employment before pension benefits are initiated. Social security pensions are subject to an earnings test; after $\$ 5,000$ is earned, each extra dollar of earnings reduces social security benefits by fifty cents.

2 This is true of defined contribution plans (such as TIAA-CREs) for three reasons: later retirement adds to the number of dollars contributed, allows previous contributions to accumulate an additional year's interest, and permits an actuarial increase in annual benefits because the expected payout period is shortened. Plans which specify benefits rather than contributions (including most employer-provided pension plans as well as Social security) usually provide more benefits to those who work longer, because of increased years of service, raises in the wage base, and a shorter expected payout period.

3 "Acutarial neutrality" means that for all possible retirement ages, the present discounted value of pension benefits over the remainder of one's lifetime is equal to the accumualted value of pension contributions up to that time.

${ }^{4}$ See, for example, Lazear (1981) on private pensions and Burkhauser and warlick on Social security. 


\section{B. Rules for Utility Maximization in a Life Cycle Context}

The foregoing features are easily combined into a quite general framework. In this section, we use this model to derive rules characterizing optimal retirement behavior. Sections II and III compare existing theoretical and empirical studies against this framework.

Utility (U) is a positive function of the lifetime consumption vector $(\vec{C})$ and of the lifetime leisure vector $(\vec{L})$ :

$$
\text { (2.a) } U=U(\vec{C}, \vec{L}), \quad U_{1}>0, U_{2}>0 \text {. }
$$

Consumption increases with income $(\vec{Y})$ :

$$
(2 . b) \text { 员 }=C(\vec{Y}), \quad C^{\prime}>0 \text {. }
$$

Income depends positively on earnings (net of taxes and pension contributions) until retirement (R), ( $\left.E_{1}, E_{2}, . ., E_{R}\right)$, and on pension benefits in each remaining year of life, $\left(P_{R+1}\right.$, $\left.\mathrm{P}_{\mathrm{R}+2}, \cdot \cdot, \mathrm{P}_{\mathrm{T}}\right): \underline{1} / \underline{2}$

$$
\text { (2.c) } \begin{aligned}
& \vec{Y}=Y\left(E_{1}, E_{2}, \cdot . \cdot E_{R} ; P_{R+1}, P_{R+2}, \cdot ., P_{T}\right), \\
& Y_{t}>0 \quad \forall t .
\end{aligned}
$$

Let $\vec{W}$ be some aspect of working that increases pension benefits. 3 If retirement is postponed, or if $\vec{W}$ is greater, the benefit in each year after retirement is higher:

\section{1)}

The length of life (T) is assumed known with certainty. 2/

If work in a post-retirement job is allowed for, an extra vector of terms running from $R+1$ to $T$ would enter into ( $2 . c)$. To avoid complicating the model further, we assume in what follows that post-retirement work is not chosen, either because the option is not available or because the individual does not elect it.

$3 /$

W might alternatively be years of service, wage in the highest $\alpha$ years preceding retirement, contributions to a pension

fund, or some combination of these. 
(2. a) $P_{t}=P_{t}(R, \vec{w}), P_{t_{1}}>0, P_{t_{2}}>0$

Let the aspect of working that affects pension benefits, $(\vec{W})$ be a non-decreasing function of lifetime labor $(\vec{H})$.

$$
\text { (2. e) } \vec{W}=W(\vec{H}), \quad W^{\prime} \geq 0 \text {. }
$$

Finally, hours of work $(\vec{H})$ and of leisure $(\vec{L})$ exhaust the hours in a year:

$$
\text { (2.f) } \overrightarrow{\mathrm{H}}+\overrightarrow{\mathrm{L}}=\overrightarrow{\text { constant. }} \text {. }
$$

Collapsing (2.a-f) into a single equation, we have:

(3) $U=U\left\{C\left[E_{1}, \ldots E_{R} ; P_{R+1}(W(\vec{L}), R), \ldots, P_{T}(W(L), R)\right] \vec{H}\right\}$

The individual's goal is to maximize utility $U$ by choice of a labor supply path $\overrightarrow{\mathrm{H}}$. The control variable is the amount of labor supplied in each period.

Consider what happens if the individual supplies more labor. The intensive and extensive margin may be distinguished:

a) Extia hours of work within some year holding the the nuinber of years in the work life constant.

Such an increase in labor supply on the intensive margin has four effects: it may raise earnings, it may raise pension benefit per year, it leaves unchanged the number of years of pension benefits, and it reduces leisure.

$$
\text { (4a) } \begin{aligned}
& \frac{\Delta\left[E_{1}, \ldots, E_{R}\right]}{\Delta H_{j}} \geq 0 ; \\
& \frac{\Delta P_{t}}{\Delta H_{j}} \geq 0, \quad \forall t \geq R ; \\
& \frac{\Delta R}{\Delta H_{j}}=0 ; \\
& \frac{\Delta \vec{L}}{\Delta H_{j}<0 .}
\end{aligned}
$$


Taken by themselves, each of the first two effects may raise utility, while the fourth effect, by itself, lowers utility. Hence, whether extra hours of work raise or lower utility is ambiguous and depends on the parameters of the particular individual'sutility function and income opportunities. Utility is maximized when no possible change in hours produces income gains worth more than the loss of leisure.

b) Extra years of work holding the number of work hours in a year constant.

Such an increase in labor supply from $R_{\text {orig }}$ to $R_{\text {new }}$ has four effects on the extensive margin: "raises earnings, raises pension benefit per year, lowers the number of years during which pension benefits are received, and reduces leisure:

$$
\begin{aligned}
& \text { (4.b) } \frac{\Delta\left[E_{1}, \ldots, E_{R}\right]}{\Delta R}>0 \text {; } \\
& \frac{\Delta \mathrm{P}_{\mathrm{t}}}{\Delta \mathrm{R}}>0, \quad \forall t \geq \mathrm{R}_{\text {new }} \text {; } \\
& P_{t} \text { falls to zero } \forall t 3 R_{\text {orig }}{ }^{<t<R_{\text {new }}} \text {; } \\
& \frac{\Delta \vec{L}}{\Delta \mathrm{R}}<0
\end{aligned}
$$

Each of the first two effects raises utility, while each of the latter two lowers it. Hence, whether working additional years raises or lowers utility depends on the parameters of the particular individual's utility function and income opportunities. Utility is maximized when no possible change in years worked produces gains in earnings and in pension per year worth more than the loss of years of pension benefits and of leisure years. 
C. Conclusions

Life cycle theory specifies that labor supply and retirement status in any period depend upon earnings and pensions in all periods. In section II we shall consider how individual confronting different earnings and pension streams would be expected to differ with respect to retirement behavior, and in section III, review empirical evidence on these effects. 
II. Theoretical Specifications in the Literature

The theoretical literature addressing various aspects of pensions, earnings, retirement, and life cycle labor supply is voluminous. However, a much more limited number of studies considers how pensions and earnings affect retirement decisions and life cycle labor supply. In this section, we review the available literature on the effects of pensions and earnings on retirement. These studies, in order are: Feldstein; Kotlikoff; Pellechio; Boskin and Hurd; Burtless and Hausman; Zabalza, Pissarides, and Barton; Burkhauser and Quinn; Reimers; Sammartino; Gordon and Blinder; Hemming; Fields and Mitchell; Sheshinski; Burbidge and Robb; MacDonald and Carliner; Gotz and MCCall; Crawford and Lilien; Gustman and Steinmeier; and Clark and Joinson. ${ }^{1}$ A brief outline of the structure of each model comes next, followed by a comparison of their similarities and differences and then by a statement of the comparative dynamic results that emerge.

$\overline{1_{\text {Five }}}$ lines of research also appear in the literature which, though tangentially related to the effects of pensions and earnings on retirement, do not deal directly with this question. We mention them here so that the reader may understand that these literatures do not offer guidance on the question at hand. Many of these studies are surveyed in Campbell and Campbell; Clark, Kreps, and Spengler; and Clark and Spengler. Besides the models reviewed below, there are other theoretical life cycle models. These others address choices of education, work, and leisure over the life cycle. Among the most fully-developed of these analyses are the works of Ben Porath, Ghez and Becker, Heckman, and Ryder, Stafford and Stephan. These studies explicitly analyze individual workers' lifetime decisions, paying particular attention to the interdependencies between past, current, and future alternatives and constraints which shape people's actions. However, because these studies are directed toward understanding individuals' decisions to invest in education and training, they do not analyze the retirement decision in any serious way. In particular, Ben Porath assumes away retirement by adopting an infinite 


\section{l continued}

time horizon, while the other authors assume the worker never retires. These models should not be faulted for failing to do well something for which they were not designed.

A second set of models considers retirement decisions in a life cycle context but does not pay serious attention to the structures of pensions and Social security as determinants of retirement behavior. Examples in the economics literature are the works of Weiss, Blinder and weiss, Driffill, Lazear (1979), and cotterman. Outside of economics, other social scientists, particularly sociologists, have conceptualized retirement in a life course perspective; see for instance Abeles and Riley.

A third group has provided a detailed examination of the budget set facing older workers, taking due account of kinks, discontinuities, and other features of pension and earnings opportunities. This is not done, however, in a life cycle context. Examples are Boskin, Bulow, and Honig and Hanoch.

A fourth group of models looks at pensions but does not focus on retirement decisions. Examples are some of Feldstein's works on the effects of Social security and private pensions on savings, Smith's and Schiller and Weiss'(1980) investigations of the economics of underfunded pensions in terms of compensating differentials; studies by Munnell, and Clark and McDermed on the effect of inflation on pensions; and the works of many on the adequacy of retirement income (see Clark, Kreps, and Spengler; Robertson or Schulz for reviews of these literatures). The Pensions Program at the National Bureau of Economic Research has produced several studies on pension fund assets (see for instance the references in Tepper) and pensions as they relate to compensation packages (see for example Eatcn and Rosen, Mitchell, and Taubman). Since these studies do not consider explicitly the employment and retirement decisions of older workers, we do not incorporate them into our present review of the literature.

A fifth literature looks at the optimal design of retirement systems. Examples are the studies by Diamond and Mirrlees, Hu, and Hagens on the Social Security system. These studies address general equilibrium aspects of Social security and private pensions, often in a sophisticated way; but the retirement decision process embodied in these models is not very informative. (Diamond and Mirrlees' model, for example produces the result ( $p .324$ ) that ". . . the consumer is indifferent about his date of retirement.") On the other hand, studies like those of the President's Commission on Pension Policy are realistic institutionally but lack a formal analytical structure for characterizing and designing optimal retirement systems. A Worthwhile direction for future research would be to integrate the general equilibrium models or Social security from the public economics literature with the life cycle models of retirement from the labor economics literature, using realistic assumptions about Social security and private pensions. Such analyses await future study. 
A. The Structure of Existing Models

Feldstein's studies of the Social security system set off the recent surge of interest in the economics of pensions. By means of simple examples in a two period earnings and consumption model, he showed that some individuals' total lifetime work effort might be invariant to social security while social Security might cause others (those who might have otherwise gone on working after 65) to retire earlier. For the first group of individuals, public saving would substitute for private saving leaving total labor supply unaffected, while for the second, Social security "acts as a combination of an annual lump sum grant and a tax on earnings after the standard retirement age. The result is to reduce the labor supply of pension recipients, generally through eariier retirement." (p.908) Proceeding to aggregative analysis, Feldstein introduced the notion of a Social security wealth (SSW) variable, defined as the total value of normal retirement benefits obligated by the Social security system, ignoring contributions. Retirement benefits available to workers at ages other than the normal retirement age were not considered. Feldstein used this variable in a Modigliani-type macro consumption function and found that SSW reduced aggregate savings by a substantial percentage. It remained for his students, Kotlikoff and Pellechio, to extend the SSW notion in more micro directions.

Kotlikoff's paper recognizes that Social Security wealth can also be defined for dates other than the normal retirement age, and concludes that "Social security may induce early retirement due to an implicit tax on post-62 earnings." 
Beyond this, Kotlikoff's main contribution is empirical (see Section III below).

Pellechio's theoretical approach, like Kotlikoff's, derives from Feldstein's notion of Social security wealth, but takes the notion one step further theoretically by linking it with a microeconomic labor supply model. Following upon recent analyses by Gronau, Heckman, Hall, and others, Pellechio (1978) posits two equations:

$$
\begin{aligned}
& \text { Market wage equation: } \text { in } W=X \alpha+e_{1} \\
& \text { Reservation wage equation: } \text { in } S=Y B+\gamma K+e_{2},
\end{aligned}
$$

where $\mathrm{X}$ and $\mathrm{Y}$ are vectors of determinants of market wages and reservation wages respectively, $k$ is the amount of work time, and $e_{1}$ and $e_{2}$ are error terms. Different individuals supply different amounts of labor according to their particular values of $\mathrm{X}$ and $\mathrm{Y}$. If it is assumed that the individual chooses to work when the market wage exceeds the reservation wage, this would be a standard single-period labor supply model. To try to make it a life cycle labor supply model, Pellechio includes a variable for Social Security wealth (SSIV) defined for one particular age. Adding this variable to the market and reservation wage equations above yields $\mathrm{Y}_{\beta}+\mathrm{e}_{2}<\delta S \mathrm{SW}+\mathrm{X} \alpha_{\alpha}+\mathrm{e}_{1}$ as the participation condition, or $\mathrm{P}$ (participate) $=\mathrm{P}\left(\mathrm{e}_{2}-\mathrm{e}_{1}<\delta S \mathrm{SW}\right.$ $+\mathrm{X} \alpha-\mathrm{Y} \beta)$. By further specifying the form of the errors $e_{1}$ and $e_{2}$ and with additional derivations Pellechio arrives at an econometric specification of the retirement probability as a function of a number of wage determining and reservation-wagedetermining variables plus a single value of Ssiv. Note, however, that this rendering of older persons' labor supply decision 
takes no account of alternative earnings or retirement income streams available at different retirement ages.

In a more recent paper (1981), Pellechio extends the simple model described above in three directions. To the reservation wage equation, he adds a measure of Social security payroll taxes the worker contributes over his worklife, thus taking into account a variable ignored in previous studies. In the market wage function, he includes a measure of the Social security benefits a worker would forego if he postponed retirement by one year. He also incorporates the gain in future SSW obtained by postponing retirement by one year. In so doing, the model is extended to take into account several institutionally relevant features of the Social Security system that had been excluded in his earlier study. Nonetheless this more. recent study still does not recognize the role of private pension and earnings streams at all possible retirement dates, and limits its attention to Social security benefit increases obtained for only one more year of work. Thus it captures more but not all of the relevant economic variables determining the retirement decision.

Boskin, Boskin and Hurd, and Hurd and Boskin. These papers are motivated more by empirical concerns than by theoretical ones. In the paper by Boskin alone, a life cycle model is presented, but it is an appendix disjoint from the body of the paper. The appendix sets up the individual as maximizing the present discounted value of utility, where the arguments of the utility function are additively separable and the instantaneous utility function depends on consumption 
of goods, $\mathrm{X}$, and leisure, L:

$$
\int_{t=0}^{T} e^{-r t} U(X, L) d t
$$

The constraint is $\stackrel{0}{K}=r K+W(t)(T-K(t))-P(t) X(t)$, where $K$ is assets, $K$ saving, and $W(t)$ and $P(t)$ are the after-tax wage rate and price of consumption goods. T denotes two different things: the number of periods in the objective function, and the number of hours per period in the constraint equation. Note the absence of both Social Security and private pensions from this budget constraint. Hence, this is a life cycle model without pensions. The model in Boskin's text, on the other hand, while considering the real-world Social security benefit structure, completely ignores life cycle features. Using Figures la-ld, Boskin shows that some individuals are unaffected by Social Security: those in Figure la work despite being eligible for Social security while those in Figure lb retire completely and would do so even in the absence of Social Security. But for other individuals, Social security does affect retirement, inducing full retirement in Figure lc and partial retirement in Figure ld. This model, unlike most, allows for partial work rather than assuming an all-or-nothirg choice, but the life cycle feature is absent. The same single period model is used in the subsequent paper by Boskin and Hurd. The third paper is primarily empirical and is reviewed below. Similar approaches (using a single-period model to analyze a trichotomous dependent variable) were used by Burtless and Hausman and by Zabalza, Pissarides, and Barton. Burtless and Hausman's sample consisted of U.S Gorernment emplnyees; their 

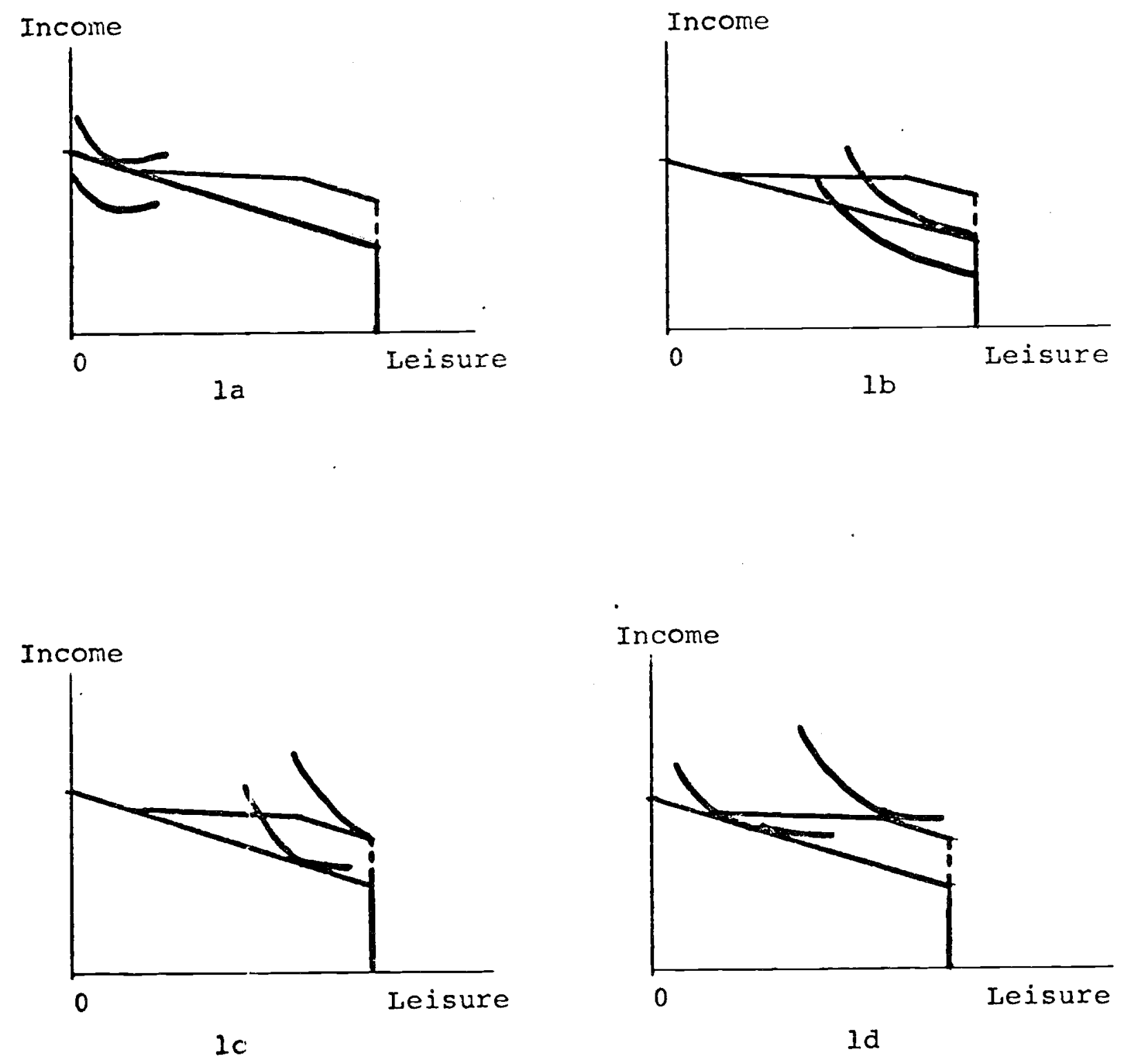

Figure 1 
dependent variable was whether at a subsequent date, the individual was still working for the government, working the private sector, or unemployed. Zabalza, Pissarides, and Barton studied the choice between full-time work, part-time work, and retirement for a sample of older persons in the U.K. Theoretically, posing retirement as a discrete data problem is an interesting idea. Life cycle aspects have been integrated into the theory of discrete choice by Gustman and Steinmeier; see below.

$$
\text { Burkhauser, and Burkhauser and Quinn. Burkhauser's }
$$
theoretical model (1976) was the first life cycle model of retirement that took real world pension structures into accourt. It was explicitly formulated in reaction to the absence of life cycle considerations in earlier models. In Burkhauser's world (1979, p. 64): "In contrast to the approach of previous investigators (Boskin, Quinn), it is not simply the size of the annual pension payments, but the present value of the pension, that emerges as theoretically important." By considering the gain (or loss) in pension value if one takes early retirement rather than waiting until the normal retirement age, Burkhauser captures one important component of life cycle models. His theoretical discussion indicates his awareness of other relevant life cycle factors (1979, pp. 64-5):

If the acceptance of a pension were not related to leaving one's job, the timing of its acceptance would be unambiguous. Given a choice among different yearly payments $\left(B_{S}\right)$ based on age ( $s$ ) when accepting a pension, a worker would accept a pension at the age that yielded a stream with the greatest present value [A(s)].... Accepting a pension usually requires leaving the job, which suggests that loss of wages and fringe benefits must be taken into account... Earnings from the job in each period ( $w_{i} t_{i}$ ), where $w_{i}$ is his wage rate (including fringe benefits) and $t_{i}$ is time spent on the job, are considered totally lost to the worker taking the early pension. 
In the specific formulations of his theoretical relationships (his equations 2 and 3 ), he has the individual evaluating only two possibilities (retirement at present versus retirement at 65) rather than the whole range of alternatives (the possibility of retiring sometime between the present and 65). Also, his 1979 study makes no mention of the gain or loss in Social Security benefits if retirement is postponed. Nonetheless, Burkhauser's theoretical model represents a substantial advance in modeling the effects of pensions or retirement. As noted below in section III, his empirical studies are also among the better of the applied studies.

In two more recent papers, Burkhauser develops his theoretical and empirical arguments further. Burkhauser (1980) focuses on the asset value of social security benefits and suggests that this measure, because it is life cycle based, is more appropriate than a comparison of one year's pension benefits with that year's earnings. Burkhauser and Quinn (1980) treat private pension and Social Security together and consider their asset value, $A(s)$, along with wages, $w(s)$, in an indirect utility function:

$$
\mu=f(w(s), A(s)) .
$$

The individual's goal is to choose that work path which maximizes $\mu$. This specification highlights Burkhauser and Quinn's fundamental point that ". . . the trade-off between potential wages and potential changes in the asset value of the pension is the crucial financial factor in the decision to separate from a job." (p. 4l) While we agree with this point, what is missing from this analysis is an explicit 
specification of the form of the indirect utility function and of the tradeoffs implicit in the budget contraint. Other authors have made considerable headway on this problem. Their contributions are reviewed below.

Reimers' work in 1977 came after Burkhauser completed his dissertation (1976) but before the publication of his first article (1979). Her chapter on the theory of retirement builds on Burkhauser's analysis but adopts a fuller life cycle framework. She notes, quite correctly, that it is necessary to compare retirement at present with all possible retirement ages, not just 65 alone as Burkhauser had done. In the most general version of her model, the individual's problem is to choose an optimal hours path as a function of present and future wages, present and future job opportunities, and present and future pensions. Retirement by her definition occurs when the individual leaves the primary employer and accepts a pension. The optimal age of retirement is solved using optimal control techniques.

In Reimers' model, the retirement decision is made as follows. If the individual works one more year, the change in well-being ( $z$ ) associated with a unit change in ace of retirement (a) is:

$$
\begin{aligned}
\frac{\partial z}{\partial a} & =\frac{1}{\pi(a)}\left[\left(w_{a m}-w_{a m}^{\prime}\right) T_{a m}-P_{a}(a)-S_{a}(a)\right] e^{-r a} \\
& +\int_{a}^{D} \frac{1}{\pi(a)} \frac{\partial P_{t}(a)}{\partial a} e^{-r t} d t+\int_{a}^{D} \frac{1}{i(a)} \frac{\partial S_{t}(a)}{\partial a} e^{-r t} d t \\
& -\frac{1}{\pi(a)} \frac{\partial \pi}{\partial a} z(a)
\end{aligned}
$$

where $W_{a m}=$ wage a man would receive from main employer if he retires at age a; 


$$
\begin{aligned}
\mathrm{w}_{a m}^{\prime}= & \text { wage a man would receive from next best } \\
& \text { employer if he retires from main employer at } \\
& \text { age a; } \\
\mathrm{T}_{a m}= & \text { time worked } \\
\mathrm{P}_{\mathrm{a}}(\mathrm{a})= & \text { private pension in year a if he retires in year } \\
& \mathrm{a} \text {; } \\
\mathrm{S}_{\mathrm{a}}(\mathrm{a})= & \text { Social security pension in year a if he retires } \\
& \text { in year a; } \\
\mathrm{P}_{t}(\mathrm{a})= & \text { private pension in year } t \text { if he retires in year a; } \\
\mathrm{S}_{t}(a)= & \text { Social security pension in year } t \text { if he retires } \\
& \text { in year a; } \\
\mathrm{D}= & \text { date of death; } \\
\pi(a)= & \text { unit cost of commodities produced in year a, which } \\
& \text { subsumes hours decisions and shadow price of time. }
\end{aligned}
$$

Neglecting the $\pi^{\prime} s$, this equation has a clear interpretation.

The term in brackets on the right hand side is the extra earnings (hourly wage multiplied by time worked) if one works another year, less the private pension and Social security benefit foregone in that year. The first integral represents the change in present value of private pension benefits if retirement is postponed one year, while the second is the corresponding figure for Social security. The last term is the change in the cost of commodities. The $\pi(a)$ terms impose utility values on each of these incomes taking account of the work needed to produce them. To sum up this expression for retirement behavior, the individual is assumed to balance the gain (or loss) in utility from more income but less leisure now, against the gain in utility from more income from private pensions and Social 
Security later if retirement is postponed. The first order condition specifies that he retires when the two are equal, i.e., $\frac{\partial Z}{\partial a}=0$.

Reimers' model comes close to deriving the behavior of interest to us, namely, the effects of changes in wages and changes in pensions (both public and private) on work hours and retirement. Her formulation differs from what we would want ir two respects: she assumes wages are constant, when we would have the individual considering how wages would change if retirement is postponed; ${ }^{l}$ and in the specific solution she actually displays, the optimal work/leisure path is derived implicitly but is never stated explicitly or characterized.

Sammartino (1978) constructed a model which, like Reimers', adopts an optimal control framework. The individual must decide how to spend his time now and in the future in order to maximize the present discounted value of goods (X) and leisure (L) :

$$
\int_{0}^{T} e^{-q t} U(X, L) d t
$$

The decision-maker begins with an injtial stock of assets. If he works in a period, he receives an income which adds to his stock of assets. Then he doesn't work, he receives the utility from leisure. Sammartino uses optimal control to derive the utility-maximizing path. In the absence of a pension, his equation $13^{\prime}$ gives the change in leisure along this optimal path as:

$$
\stackrel{0}{L}=\left(q-r+\frac{\dot{w}}{w}\right) \lambda_{0} e^{(q-r) t} w / U_{L L},
$$

\footnotetext{
${ }^{1}$ Some life cycle models in fact place wage change at the core of the explanation for why people retire.
} 
where $\stackrel{\circ}{L}$ is the change in leisure, $q$ is the individual's discount rate, $r$ is the rate of return on assets, $\stackrel{w}{w} / w$ is the rate of growth of wages, $\lambda_{0}$ is the implicit value of a marginal dollar of initial wealth, and $U_{L L}$ is the second derivative of utility with respect to leisure (assumed negative). If the first term in parentheses $(q-r+\stackrel{\circ}{w} / w)$ is negative, leisure will increase over time (i.e., $\stackrel{0}{\mathrm{~L}}>0$ ). If the increase is sufficiently rapid, the individual reaches the point of full leisure, hence zero work. Thus, if retirement is definea as zero work, an individual is more likely to retire the greater is the difference between the market rate of interest ( $r$ ) and the individual's subjective discount rate $(q)$ relative to his rate of wage growth $(\dot{w} / w)$.

Thus far, the model does not build in pensions explicitly. Once a pension is allowed for, and receipt of pension benefits is conditioned on ceasing to work for the principal employer, the system becomes much more complicated. Sammartino sets up but does not solve for the optimum in this expanded system. He notes that the age of retirement depends on the pre and post retirement wages, the level of pension benefits, the change in pension benefits from the delaying reitrement, the interest rate, the discount rate, and the otpimal amount of work time in both the pre and post retirement periods. However, this paper does not develop the comparative dynamics implicit in the model. I

Gordon and Blinder's paper represents a careful attempt

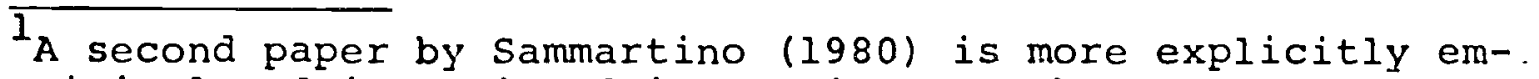
pirical and is reviewed in section III, below. 
to tie together a full-fledged life cycle model of retirement with an institutionally realistic pension structure. An accompanying paper (Blinder, Gordon, and Wise) addresses institutional aspects of Social security and conseguent effects on work incentives in greater detail.

Their retirement model has three periods: the past (period 0), the present (period 1), and the future (period 2). Individuals of different ages have pasts and futures of different lengths $\left(\mathrm{T}_{\mathrm{O}}\right.$ and $\mathrm{T}_{2}$ years respectiveiy). The individual's problem is to decide how much work to do at present $\left(L_{1}\right)$ and how much to do in the future $\left(L_{2}\right)$, taking the past as given. Denoting the utility from consumption in a period by $U\left(C_{i}\right)$ and the utility of leisure in a period by $V\left(L_{i}\right)$, the decision-maker seeks that combination of work and consumption which maximizes the following utility function:

$$
J=T_{0}\left\{J\left(C_{0}\right)+V\left(L_{0}\right)\right\}+\frac{U\left(C_{1}\right)+V\left(L_{1}\right)}{1+\rho_{1}}+T_{2} \frac{U\left(C_{2}\right)+V\left(L_{2}\right)}{\left(1+\rho_{1}\right)\left(1+\rho_{2}\right)}
$$

Retirement occurs when, following Gordon and Blinder's definition, the number of hours worked for pay goes to zero.

What role do they give to pensions in affecting retirement? The way they think about it is that workers accrue pension rights while working and these accruals are considered to be wages at the time of the accrual. Workers, however, do not necessarily value the pension contributions as they do money wages. They define a parameter, lambda, which indicates the subjective weight given by workers to pension contributions relative to money wages. This formulation obligates them to maintain a direct link between pension contributions and pension benefits based on an (empirically) unobserved weighting factor. 
It would seem better as a general proposition to drop that link and to treat direct correspondence between pension benefits and pension contributions as a special case.

This three-period model, with the future being treated as a single period, does not by its very nature afford examination of allocation of time within the future. That being the case, it is very hard to imagine why an optimal solution would be to work now and not work in the future, since that would be a sharply discontinuous result in a model with no apparent discontinuities. In fact, the authors have discontinuities within the future in mind: deterioration in health, falling wages, and changing preferences in favor of leisure. But these do not enter explicitly into their theoretical model.

Hemming proposes a more general life cycle model of retirement, where the individual selects a retirement date $\left(R_{L}\right)$ to produce the largest income flow over his lifetime. The individual is assumed to work full time up to the age of retirement and not to work thereafter; no part-time employment is allowed for. Income streams depend explicitly on the worker's choice of retirement date, since they are composed of earnings until the date of retirement, private pension income thereafter, and public pension benefits from some institutionolly set age until death. The private pension benefit stream is structured to depend directly on the worker's retirement date, which is an essential feature of real-world pension systems. However, it is assumed that the public pension always pays a flat amount ( $p)$. In equation form, the model assumes that the worker maximizes, by choice of $R_{1}$, 
the following:

$$
Y\left(R_{1}\right)=\int_{0}^{R_{1}}(1-\alpha) w(t) d t+\int_{R_{1}}^{L} \gamma\left(R_{1}\right) d t+\int_{R_{2}}^{L} p d t
$$

where:

$$
\begin{array}{ll}
(1-\alpha) w(t) & \text { is the net wage in year } t \\
\gamma\left(R_{1}\right) & \text { is the private pension amount received per year if } \\
& \text { the retirement date of } R_{1} \text { is chosen } \\
I & \text { is length of life } \\
R_{2} & \text { is the date public pension benefits begin } \\
Y\left(R_{1}\right) & \text { is the present value of future income streams } \\
& \text { (discounting is ignored for expository convenience). }
\end{array}
$$
that it explicitly recognizes that the life-cycle model requires the worker to compare the gains in pension income from a longer work life against the loss in earnings from retiring earlier. The first order condition is stated clearly: "at the margin, the increase in the present value of net wage income plus pension benefits after retirement from postponing retirement...must equal the present value of the pension income foregone through later retirement." (p. 170). An implicit function for the optimal retirement date is derived, and implications of changes in pension parameters noted. For instance: an increase in the flat benefit provided by the public pension always induces earlier retirement because retirement is made more lucrative than work. An increase in the tax rate on earnings $(\alpha)$ is found to produce postponed retirement. However a change in $\gamma$ has theoretically ambiguous effects on the optimal retirement date, depending on other 
parameters in the model. Another novel feature of the study is that the pension is not necessarily actuarially neutral. Hemming assumes an income-maximization framework, which is advantageous theoretically in focusing attention on the role of pensions and earnings in determining retirement but unrealistic empirically. A more serious limitation is that the functional forms used by Hemming to characterize public and private pension plans are too simplistic and need to be made more realistic.

Fields and Mitchell (1981) also model how an incomemaximizer chooses the optimal age-of-retirement when each period's work hours are given. That paper showed that a necessary and sufficient condition for an income maximizer ever to retize is that the annual pension benefit must cut the net earnings function from below. If this condition holds and if earnings and pension benefit per year are both linear functions of time, $E=m+n t$ and $\pi=p+q t$ respectively, then the income-maximizing age-of-retirement is given by $R^{\star}=\frac{m-p+q T}{2 q-n}$. This optimum is found by balancing off the gain in earnings and in pension benefits from working one more year against the loss of one year's pension benefits. We refer to this as the "life cycle rule." Other decision rules are shown to lead to retirement ages that differ systematically from the optimum, as shown in Figure 2:

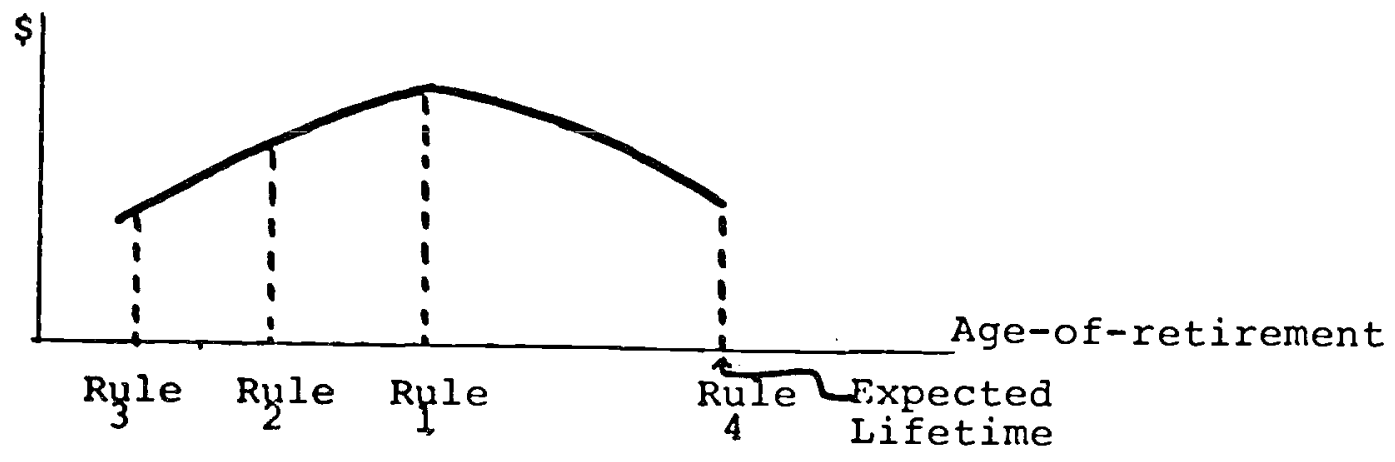


where:

$V(R) \quad$ is present discounted value of lifetime income;

Rule 1: Retire at the age when the last year's

earnings are just offset by the loss in present discounted value of pension benefits by postponing retirement one more year.

Rule 2: Retire when the current year's pension equals the current year's earnings.

Rule 3: Retire when pension wealth (PDVP) is maximized. Rule 4: Retire when the replacement rate (the ratio of pension benefits to pre-retirement earnings) is maximized.

The retirement ages using Rules 2 and 3 are definitely. less than the optimum for an income-maximizer and the retirement age using Rule 4 is too late; but where the ages using Rules 2 and 3 are relative to one another depends on specific parameters. Additionally, comparative dynamics were considered for the income maximizer. It was shown that although conventional wisdom usually holds that higher pensions lead to earlier retirement and higher wages to later retirement, the reverse results are also possible; examples were presented to show that some pension increases may result in earlier retirement and some wage increases may result. in later retirement. These possibilities are also noted by Burbidge and Robb and by Sheshinski in studies reviewed below.

Sheshinski presents a thorough analysis of the problem confronting a utility-maximizer who values both consumption and leisure and whose control variable is the number of periods worked before retiring. He first analyzes a highly 
stylized model at length and then generalizes it in more realistic ways though in less detail. Both models contain a rigorous development of the life cycle framework and the decision rule it implies: To paraphrase the rule, the individual assesses the direct loss in utility from further postponement of retirement, weighs this loss against the utility value of the gain in present value of earnings and pension receipts, and chooses as his optimum the point at which these gains and losses are equal. Another result of interest emerges from his more general model: that the effects of higher wages and higher pensions on the age of retirement are ambiguous depending on the parameters of the respective functions. Sheshinski deserves credit as the first to develop these ambiguities rigorously. Despite these strengths, his conclusions are limited in generality owing to his assumption of actuarial neutrality of pensions, which is unrealistic in most circumstances.

Burbidge and Robb offer a more realistic analysis, in that they do not require actuarial neutrality. Their basic framework is illustrated in Figure 3 for an individual whose utility function gives positive weight to consumption and time in retirement. Let $F M$ be the individual's lifetime budget constraint with no pension under alternative retirement dates (measured from right to left---time spent in retirement is measured from left to right). A representative indifference curve is drawn as $P Q$ in Figure 3a; an individual with budget constraint FM and preference mapping $\mathrm{PW}$ would retire at a* years of leisure. Introducing a pension plan shifts the lifetime budget constraint. How it shifts depends on the balance 
3a. Choice of Retirement Age

Consumption

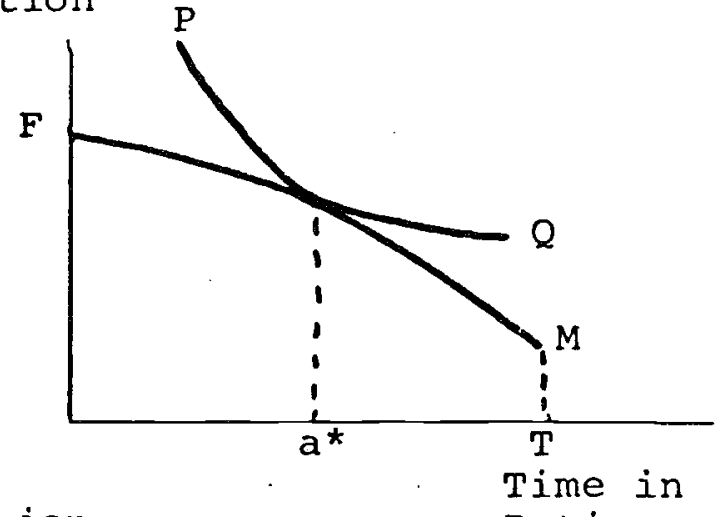

3b-d. Introduction of Alternative Pension Plans

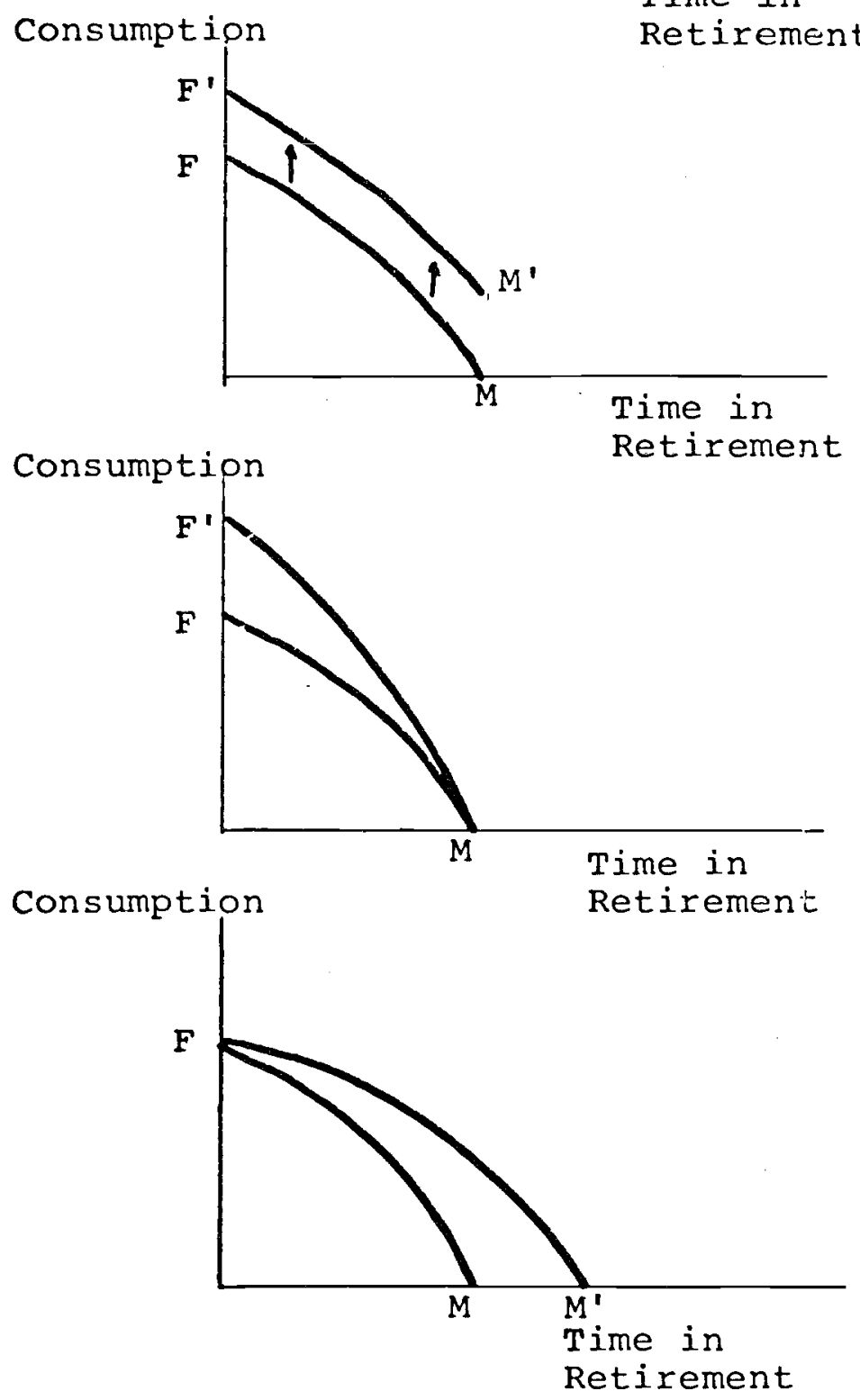

Figure 3 
between pension benefits and pension contributions at each age. Three possibilities are illustrated in Figures $3 b-3 d$.

The remainder of Burbidge and Robb's analysis consists of analyzing the consequences of these different pension structures for the age of retirement.

Another paper that pursues a similar approach is that of MacDonald and Carliner. They too work in a framework assuming utility-maximizing that hours of work are fixed within each period. The authors examine how the optimal retirement date varies as pension and other parameters change (assuming interior solutions). Of particular interest is their formulation of a specific pension function, which is nonlinearly related to the age of retirement. Some unexpected results are apparently peculiar to their specific pension function; for instance they find that inclusion of fewer years of salary in the pension base calculation induces earlier retirement, and increases in the penalty for early retirement probably induce earlier retirement.

Gotz and McCall have sketched a similar way of analyzing the life cycle retirement problem, but focus heavily on sources of behavioral differences across people. Their primary interest is in determining retention rates of military personnel, and in particular in evaluating how the military retirement system affects an cfficer's choice of retirement dates. The individual is posited to compare the extra earnings and higher pension produced by one more year of work, against the lost benefits foregone by not retiring immediately. In addition the authors acknowledge that nonmonetary factors may play an important role, and devote a great deal of attention to modeling these 
other factors, which enter via an individual specific utility function (that varies across people). ${ }^{1}$ They also relax the assumption of perfect certainty, so that both economic factors and random variation are allowed to determine the optimal retirement date. Much of this work is still in progress, so that the final form of the theoretical equation is not yet clear, but their approach appears to be one of the more sophisticated analyses of a life cycle retirement problem. Or the other hand, the model has not yet incorporated many specific institutional features of military pensions and the Social Security system, and how these interact to determine retirement. Crawford and Iilien approach the retirement question in a somewhat different but systematic manner. They begin with a highly-stylized model (which has its origins in the work of Feldstein and Burbidge and Robb) that assumes that pensions are actuarially neutral, capital markets are perfect, and length of life is known with certainty. In this "base case" model pensions have no effect on retirement; the individual merely substitutes savings through the pension fund for savings he would have done on his own, borrowing or lending in the capital market to achieve the desired timing of consumption and savings over the life cycle. Crawford and Lilien then relax the perfect capital market assumption, and find that higher required pension contribution levels produce earlier retirement. This is explained by the declining marginal utility of consumption at higher income levels, and the tendency to use some of these

I Two papers, one by Burtless and Hausman, the other by zabalza, Pissarides and Barton, also allow for differences in preferences across individuals. Neither utilizes a life cycle framework in their retirement model, however. 
forced savings to purchase additional leisure. In a model where the individual can only adjust the number of periods worked, and not hours within a period, the worker will retire earlier. Deviations from pension neutrality are also examined in some detail: for example, current social security rules apparently create an incentive to move retirement toward age 65, at least among those who would have retired later in the absence of Social security. Finally, these authors also examine the effect of an actuarially neutral pension scheme in a world with uncertain lifetimes, concluding that the insurance feature of social security creates an income effect toward early retirement, and an ambiguous substitution effect (assuming that private insurance schemes are not available). The authors have not yet combined all three features (imperfect capital markets, uncertain lifetimes, and non-neutral

pensions) into a single model. This extension awaits further research.

Finally, two new theoretical directions in the literature bear mention. Gustman and steinmeier set up a variable-hours life cycle model for a utility-maximizer. The novel feature of their work is to include the wage in an alternate job as an additional explanatory factor and the hours worked in the alternate job as an additional control variable. They do not: yet have an analytical solution to their model. Another novelty is found in the work of clark and Johnson, whose point of departure is to introduce a family context. (All other researchers considered a single individual's problem.) Like Gustman and steinmeier, they have a variable-hours life cycle 
model of a utility-maximizer; and, they too have been unable to obtain an analytical solution.

\section{B. Comparing the structures}

1. The Control Instrument

Most models of pensions and retirement assume that older workers must choose between full-time work and zero work. These so-called "age-of-retirement models" are useful since they are capable of capturing many of the interesting life cycle aspects of income opportunities and consequent work patterns. Five theoretical models have gone beyond this ageof-retirement specification to consider part-time work and variable hours models. Sammartino (1978) and clark and Johnson discuss the hours decision explicitly in a life cycle context; Reimers considers the hours decision implicitly in what is otherwise an age-of-retirement model; Boskin and Hurd evaluate semi-retirement as an option to full retirement, but do not take a life cycle approach; and Gustman and steinmeier allow for variable hours on the main job and on an alternate job. Unfortunately, their theoretical models are not yet very informative on the factors making one hours path more likely than another, for the following reasons. Sammartino assumes that hours of work decline smoothly to zero, Reimers does not display the hours path at all, Boskin and Hurd do not examine changes in hours over time, and Gustman and steinmeier and Clark and Johnson were unable to solve analytically the optimal control model they had set up. More research is needed on the forces leading alternatively to discrete switches from full-time work to zero work, from full-time work to part-time, 
or to smoothly declining hours paths.

2. The Objective Function

a. Multiperiod or Not? Since retirement and lifetime labor supply are life cycle decisions, they must be modeled in a multiperiod framework. The earliest models did not do this; they were limited to one period only. Burkhauser (in his dissertation) presented the first genuine life cycle model of retirement. His contribution to the literature was to demonstrate that the decision of when to retire depends on the present discounted value (PDV) of alternative pension streams. However, he unduly restricted the choice set by considering only the value of retiring today as opposed to retiring at the age of compulsory retirement. A life cycle approach suggests that someone facing mandatory retirement should also consider whether it might be even better to retire at some intermediate age; workers not subject to mandatory retirement should also examine the advantages of deferred retirement at all possible ages. All life cycle models after Burkhauser's have recognized that an anlysis of retirement options should consider all possible retirement dates.

\section{b. Does the Utility Function Value Leisure? Some}

authors (Hemming, Fields and Mitchell) consider incomemaximization models, thereby assuming the indivudal places no value on leisure. ${ }^{1}$ Income-maximization models highlight the effects of the budget constraint (pensions and earnings) on

\footnotetext{
IModels in which people are assumed to maximize social security wealth or private perision assets also leave aside the utility value of leisure.
} 
retirement. And, as Hemming notes (p. 171): "Although it is fairly straightforward to incorporate leisure in the model it can be shown that it does not affect the qualitative nature of the results." Most models, however, explicitly introduce leisure as well as income (or consumption) as argument in the utility function.

\section{c. How Does Leisure Enter the Utility Function?}

The most general approach is to express utility as a function of each period's consumption and leisure, as we did earlier: $\quad U=U(\vec{C}, \vec{L})$. Further specification is often helpful. The most common one is to impose intertemporal separability: $\mathrm{U}=\sum_{t} \mathrm{U}\left(\mathrm{C}_{t}, \mathrm{~L}_{t}\right) ; \mathrm{U}_{1}>0, \mathrm{U}_{11}<0, \mathrm{U}_{2}>0, \mathrm{U}_{22}<0$. Sometimes, withinperiod separability appears: $U_{t}=\phi\left(C_{t}\right)+\psi\left(L_{t}\right) ; \phi^{\prime}>0, \phi^{\prime \prime}<0$, $\psi^{\prime}>0, \psi^{\prime \prime}<0$. The previous specifications are particularly well-suited to variable hours models. However, in age-ofretirement models, a lifetime utility function is sometimes used instead: $\quad U=U(P D V Y, R E T), U_{1}>0, U_{11}<0, U_{2}>0, U_{22}<0$, where PDVY is the present discounted value of lifetime income or consumption and RET is the length of the retirement period. In the age-of-retirement models, where additional leisure can only be obtained by working fewer periods, a lifetime utility function, unlike the others, allows for diminishing marginal utility of leisure across periods. For this reason, we regard the lifetime utility function as the most appropriate in an age-of-retirement context.

3. The Budget Constraint

The life cycle model presented in Section I maintained that the steams of several economic variables are essential 
to determining the budget constraint. They are: the earnings stream (net of taxes), the (net) private pension and social Security benefits that could be received at different ages, the contributions to private pensions and Social security, and (where relevant) the wage that could be earned on an alternate job. No theoretical study in the literature has done this.

Two problems stand out. First, some models consider only the current values of economic variables, overlooking their streams over time. This is less frequently a problem in the theoretical literature than it is in the empirical literature reviewed below, where streams of explanatory variables rarely appear.

Second, theoretical studies vary in the way they incorporate pensions in the budget constraint. Some require actuarial neutrality of pensions while others do not impose a dollar-for-dollar linkage between benefits and contributions; we prefer the latter, both for its theoretical generality and for its institutional realism. Another issue is whether models allow pension benefits per year to rise if the individual retires later. Most models have this feature but reservation wage models do not. Once again, theoretical generality and institutional realism argue in favor of such a specification. A final feature, the fact that most individuals are eligible to receive pension benefits only after retiring, has been included in most theoretical models.

4. The Decision Rule

The rules characterizing the optimal age of retirement are derived in most mode'ls by maximizing the objective function 
subject to a budget constraint and the available instruments. This is as it should be. Some models, however, use ad hoc rules instead. For example, the asset-maximization decision rule holds that the optimal retirement date is that which maximizes the asset value of pension benefits. Other criteria for determining the optimal age of retirement are even less appropriate. Two such rules are: "Retire when the replacement rate is maximized" and "Retire when pension benefit comes to equal earnings." These alternate rules are not derived directly from maximization of the objective function, and Fields and Mitchell (1981) show they err systematically.

\section{c. Results of the Models: How Pensions and Earnings} Affect Retirement. 1

It is often assumed that higher wages lead to later retirement and higher pension benefits (from Social security or private pensions) to earlier retirement. This presumption has been challenged and shown to not necessarily be true at three levels:

1. The "Base Case World." [Feldstein, Burbidge and Robb, Crawford and Lilien]. If pensions are actuarially neutral, capital markets perfect, and lifetimes known with certainty, the pension system leaves the budget constraint unchanged and hence does not affect the individual's choices of lifetime consumption and leisure and the corresponding amount of lifetime work.

These comparative dynamic predictions are for an age-of-retirement framework where the individual either works full time or else withdraws from market work altogether. Models which allow parttime work have not yielded meaningful comparative dyanmic results. 
2. The Income-Maximizer. [Hemming, Fields and Mitchell]

The income maximizer does not value leisure. Consequently,

a change in pension or earnings has no income effect, only

substitution effects. Several theoretical predictions on

comparative dynamics are available for the income maximizer: ${ }^{1}$

(a) If pension benefits are increased exogenously, by a constant number of dollars for each possible retirement age, then the retirement alternative becomes more attractive and the individual is induced to retire earlier. This is an ordinary substitution effect in response to changes in the level of pension benefits.

(b) If pension benefits are increased exogenously, by a non-uniform number of dollars for each possible retirement age, two substitution effects obtain. The ordinary substitution effect favors retirement. In addition, an intertemporal substitution effect arises since the individual now has a different amount to gain if he postpones retirement. If, for instance, pension benefits increased by a constant percentage at each age, the intertemporal substitution effect would encourage delayed retirement, because more is to be gained by retiring later. In opposition, the ordinary substitution effect encourages earlier retirement. On net, the effect of such a tilt in the benefjt formula may lead to earlier or later retirement, depending on which effect dominates. Thus pension benefit increases of this form have an ambiquous impact on retirement. ${ }^{2}$

(c) An exogenous increase in earnings ceteris paribus raises the opportunity cost of retiring. Therefore, the income-maximizing individual would substitute in favor of the (relatively higher) net earnings stream and away from the pension stream, implying that he is more likely to retire later.

(d) An exogenous drop in pension contributions, ceteris paribus, has the identical effect as in (c), and produces a substitution response favoring later retirement.

\footnotetext{
The comparative dynamics reported here apply to workers who do plan to retire during their lifetime; individuals who plan never to work or never to retire may not respond to marginal changes in earnings or pensions.

2

Specific examples illustrating these points are presented in Fields and Mitchell (1981).
} 
(e) The higher is the wage in a post-retirement job, the greater is the value of leaving the principal employer. Defining retirement as the date of leaving the principal employer and accepting a pension, an income-maximizer is more likely to retire earlier. 1

3. The Utility-Maximizer [Sheshinki, Burbidge and Robb,

Crawford and Lilien, Fields and Mitchell, MacDonald and Carliner].

For the case of a utility maximizer, satisfaction is derived

from the leisure as well as income. In this case, when the

earnings stream and/or pension stream changes, income effects

arise in addition to the substitution effects, producing even

fewer unambiguous conclusions.

(a) If pension benefits increase for every retirement age by a constant number of dollars, then ceteris paribus, both ordinary substitution and income effects are present. By the substitution effect, retirement is now more attractive, so the individual tends to retire earlier: By the income effect, full lifetime wealth is now higher and the individual tends to buy more of normal goods; if leisure is a normal good, he would buy more by working fewer periods. Thus both the substitution and income effects work in the same direction; a utility maximizer would tend to retire earlier in response to an increase in his pension benefits by a fixed number of dollars per year.

(b) If pension benefits are increased by a non-uniform amount, in addition to the effects cited for the income-maximizer in (2.b), an income effect is now also present. The pension increase raises his wealth, and the income effect leads him to retire earlier. This tends to reinforce the ordinary substitution effect, which also favors earlier retirement. But because the intertemporal substitution effect may be positive and large, the effect of a non-uniform pension increase on the age of retirement is still ambiguous for a utility-maximizer.

(c) If earnings are increased Exogenously, two offsetting effects obtain for a utility-maximizer. As in the case of the income maximizer, there is a substitution

$\bar{I}_{\text {An }}$ income-maximizer would never stop working if he could simultaneously receive a pension from his principal employer and earn a positive net. wage in a post-retirement job. 
effect: because the payoff to working is greater, the substitution effect facors later retirement. However, the utility-maximizer also has an income effect: after working the first period, the individual's wealth is greater, and the income effect tends to make the individual increase consumption of leisure and retire earlier. Thus, in general, for a utility-maximizer, the effect of increased earnings on retirement is theoretically ambiguous. This ambiguity has not been recognized by others who have looked at the comparative dynamics of this problem.

(d) An exogenous drop in pension contributions, ceteris paribus, is also theoretically ambiguous for the same reasons as in (c): the substitution effect favors later retirement and the income effect favors earlier retirement.

(e) The higher are earnings on a post-retirement job, the greater are the opportunity costs of remaining with the principal employer and of leaving the labor force completely. The incentives are therefore to accept a pension from the principal employer earlier, hastening retirement by the age-of-pension-acceptance definition. The individual may or may not leave the labor force earlier, depending on his response to the increment to his lifetime income. Thus, this too has an ambiguous effect.

\section{Theoretical Conclusions}

Life cycle theory has guided most existing theoretical models of the effects of pensions and earnings on retirement. Accordingly, in these models, how much work to do in each of $T$ periods of life depends on conditions in each and every period.

A special case of lifetime labor supply modeling has proved particularly tractable: the so-called "age-of-retirement models." In this class of models, labor supply within a period is dichotomous: the individual either works a specified number of hours or doesn't work at all. Interesting results for the effects of pensions on retirement emerge only from the age-of-retirement literature. In contrast, variable hours models have been unsuccessful in taking account of the effects 
of pensions on labor supply.

Theory suggests that six economic factors---the net

wage stream on the main job, the net wage stream on an alternate job, net private pension benefits, social security benefits, private pension contributions, and social security contributions-play a central role in determining the age of retirement. of these, three have received serious consideration; they are the wage stream on the main job, private pension benefits, and Social security benefits. The other three--the wage stream on an alternate job, private pension contributions, and social Security contributions---have largely been ignored.

How each of these variables enters into the retirement decision has undergone a change of perception in the theoretical literature. First generation models held that higher wages induce later retirement and higher pension benefits induce earlier retirement. More recent theoretical developments have shown that these earlier surmises were not necessarily correct. Theory has now shown that some wage increases can lead to earlier retirement and some to later retirement. Theory has also now shown that some pension increases lead to earlier retirement and some to later retirement. These (ceteris paribus) results may be summarized as follows: 1

\footnotetext{
In a highly-stylized "base case" (i.e., actuarially neutral pensions, perfect capital markets lifetime known with certainty) pensions have no effect on earnings. The results reported in the text are for actuarially non-neutral pensions.
} 


\section{For an Income-Maximizer:}

\section{Variable}

Increase in pension intercept

Increase in slope of pension function

Increase in earnings

Increase in pension contributions

Increase in wage on alternate job
Effect on Age-of-Retirement

Earlier

Ambiguous

Later

Earlier

Ambiguous

\section{For a Utility-Maximizer:}

\section{Variable}

Increase in pension intercept

Increase in slope of pension function

Increase in earnings

Increase in pension contributions

Increase in wage on alternate job
Effect on Age-of-Retirement

Earlier

Ambiguous

Ambiguous

Ambiguous

Ambiguous 


\section{Empirical Models in the Literature}

\section{A. Specifications}

This section, and the table on the following page, summarize several key features pertaining to empirical retirement models. The next section reviews specific empirical findings on the determinants of retirement.

The table indicates clearly the great variety of dependent variables examined in the literature. Most authors focus on a simple probability of retirement, as measured at some particular time, either on the survey date, some other year, or by the time the individual attains a specified age. Typically the definition of retirement is a labor force measure, though a few authors equate accepting a pension with retirement. Some models expand the choice set under examination to include more options; for instance, a 3-way model involving retirement, semi-retirement and full time work is the focus of the analyses by Boskin, Hamermesh, Burkhauser and §ouinn, and Gustman and steinmeier. Still other authors contemplate job change patterns as a method of examining retirement (Burtless and Hausman, for instance). Finally, a couple of empirical analyses use a continuous variable such as hours of work (in the survey week, for instance) as the labor supply measure of interest. None of these summary measures of lifetime labor supply is obviously superior to the others. No study examines hours of work patterns in all possible years, as would be consistent with the general theoretical life cycle labor supply model sketched in Section I and II above. Despite the great diversity of ways to define and analyze retirement, only Gustman and 
Steinmeier evaluate systematically the different empirical results produced by different definitions of retirement. Further work along these lines would be useful.

Empirical models also differ according to the ways in which they specify the economic variables postulated to influence retirement. Consider the six theoretical variables which theory suggests determine older workers' labor supply-namely, the net wage stream on the current job, the net wage stream on an alternative job, the net private pension benefit and contribution streams, and the social security benefit and contribution streams. To date, no empirical study takes into account the current values of all six variables, let alone their streams over time. For instance, Burkhauser's (1976) work does a good job in using a discounted flow of after-tax earnings, but assumes that the worker retired at age 65 so earnings at other ages and in other jobs are ignored. Gustman and steinmeier are careful to include a wage rate on post-retirement job, but omit consideration of taxes and earnings streams. Measures of retirement benefits used in the literature have some of the same drawbacks. Kotlikoff nets out payroll taxes from a discounted flow of social security benefits, which is more complete than others' measures; however, he considers that variable for only one retirement date. Pellechio (1981) and Burkhauser and Quinn do the best job of including both private pension and social security income streams, as well as changes in these streams if retirement were to be postponed one year. Nonetheless changes in these streams if retirement were postponed more than one year are ignored. 
$-42-$

SUMMARY OF EMPIRICAL STUDIFS OF TIE EFFECTS OF EARNIIGS AND PFNSIOIS ON RETIREMENT

\begin{tabular}{|c|c|c|}
\hline & & Economic Factors \\
\hline$\frac{\text { tudy }}{(1)}$ & $\begin{array}{l}\text { Dependent } \\
\text { Variable } \\
\text { (2) }\end{array}$ & $\frac{\text { Earnings }}{(3)}$ \\
\hline soskin $(1977)$ & $\begin{array}{l}\text { Varioue including } \\
3 \text {-way model de- } \\
\text { fining retired } \\
\text { l/4 time work añd } \\
\text { omi-retircds } 1 / 2 \\
\text { time, and not ret lred } \\
\text { otherwise. }\end{array}$ & $\begin{array}{l}\text { Grose current annual } \\
\text { earnings if reported. } \\
\text { or imputed fuli-time } \\
\text { earnings. }\end{array}$ \\
\hline soskin and Hurd (1978) & $\begin{array}{l}\text { Various including } \\
2 \text {-way model whir } \\
\text { retired=zero hours } \\
\text { of work (also has } \\
3 \text { - model). }\end{array}$ & $\begin{array}{l}\text { Gross current hourly } \\
\text { wage; net current hourly } \\
\text { wage (gross minus income } \\
\text { and rayroll tax). }\end{array}$ \\
\hline $\begin{array}{c}\text { Surkhauser (1976) } \\
\text {. }\end{array}$ & $\begin{array}{l}\text { Probability of ac- } \\
\text { cepting early pen- } \\
\text { olon in } 1965 \text {. }\end{array}$ & $\begin{array}{l}\text { PV of expected gross } \\
\text { earnings if work from } \\
\text { current age until age } \\
65 \text {, minus income tax }\end{array}$ \\
\hline Burkhauser (1979) & As above & As above \\
\hline Burkhauser (1980) & $\begin{array}{l}\text { Probability of ac- } \\
\text { cepting Social } \\
\text { Security at age } 62 \text {. }\end{array}$ & $\begin{array}{l}\text { Gross current annual } \\
\text { rcported earnings at } \\
\text { age } 61 \text {. }\end{array}$ \\
\hline $\begin{array}{l}\text { Burkhauser and } \\
\text { juinn }(1980)\end{array}$ & $\begin{array}{l}\text { 3-way model of prob- } \\
\text { ability of having } \\
\text { same job, new job. } \\
\text { no job next year. }\end{array}$ & $\begin{array}{l}\text { Gross current imputed } \\
\text { hourly wage. }\end{array}$ \\
\hline
\end{tabular}

Burtless and

Hausman (1980)

Clark and Johnson $(1980)$

cotterman (1978)

cordon and Blinder $(1980)$

Gustman and steinmeler (1981)

Hame rmesh (1981)

Hurd and Boskin

(1980)

Kotlikoff (1979)

3-way model of prob- Gross current hourly abllity of being re- wage in 1976 divided by tired, Federal em- same in 1973: imputed wage ployec, or private in 1977 and interactions. pector job next year.
Probability in labor force.

Varlous including probability in labor force, and hours $c$ ork.

Presents results for probability of labor force participation.

Various. For example, 3-way model defining retired $=0$ work, part-retired= drop of more than 408 in wages or hours on main job not retired othcrilse.

Varlous. For example, models defining retired $=$ no work, semi-retiredwark, sime work, not part time work, no also uses of full time work in a year.

Probabillts in labor force.

Expected Retirement age.
Gross current hourly wage if reported, or imputed.

Gross reported hourly wage in 1966.

PV of gross imputed annual earnings from current age to $n: 067$.

Gross imputed hourly on main job at age 63 (4 brackets); (ross imputed hourly wage on alternative job at age 65-7 (4 brackets).

Proxies

SSw as of two years before survey. by PV gross annual imputed earnings from current age to 67 .

Eligibility dummies Eligibility dumies LRUS

Gross PPW as of NLS

Data Source Pensions (5)

$\operatorname{rsin}$

Gross iwnefit if currantly receiving pension), includied in nonlabor income

None

LPHS

fits if receiving ss,

or imputed if not retired.

None

None

SSw at are 62 .

SSW at age 62 ; SSDELTA SSW at age 62
age 62 to 63 .

ss benefits eligible for in $1977 /$ imputed wage 1977 and interactions kith age. range in SS replacement sector.

Eligjbility dummy; SSW as of survey date.

SSW as of 1966
Gross profita if age 65 .

As above, but incom: taxes also subtracted.

Proxied by industry dumy variables.
Auto horke:s

As above

IPS-CFS-SS Exact llatci File

Eligibility dumies; LRHS Gross imputed PPW as of earliest age of elicibility; Gross imputed PPDLLTA if retired now vs. next year.

(Civil Service)

Gross Federal pen-

sion if retired.n

$1977 /$ imputed aross

wage 1977 and interactions with age.

Eligibility dumny: LRHS PPW as of survey date. 1966.

Elibibility dumies LRHS Federal employees 


\begin{tabular}{|c|c|c|c|c|c|}
\hline \multirow[t]{2}{*}{. } & & $-43-$ & & \multirow[b]{2}{*}{ PET I REMENT } & \\
\hline & SUMMARY OF EMPIRICAL & STUDITS OF THE FFFECTS OF & F.APHIINSS NMD PFNSIONS ON F & & \\
\hline$\frac{\text { tudy }}{(1)}$ & \multicolumn{5}{|c|}{ 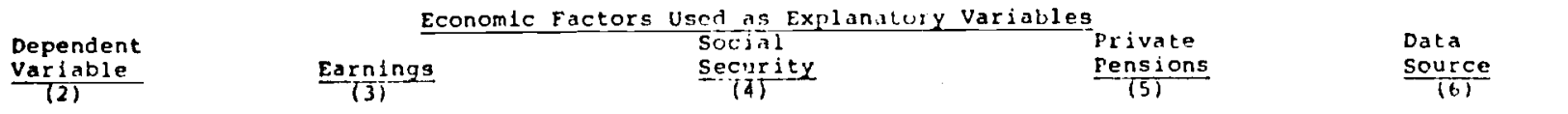 } \\
\hline Dellechlo $(1980)$ & $\begin{array}{l}\text { Probabilil; } \\
\text { labor force. }\end{array}$ & $\begin{array}{l}\text { PV of aross reported } \\
\text { annual earnings up to } \\
\text { Sozial serurity earnings } \\
\text { ceiling, I: m aqe } \\
\text { entered workforce to } \\
\text { present; Average gross } \\
\text { repor', annual earnings. }\end{array}$ & 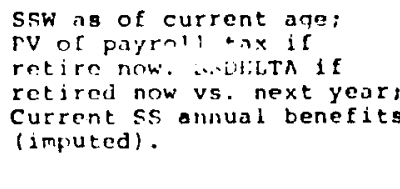 & 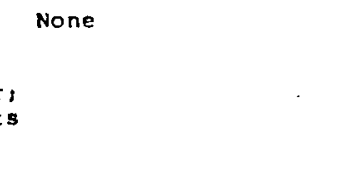 & $\begin{array}{l}\text { Ins-cosest } \\
\text { Exict sinech } \\
\text { file }\end{array}$ \\
\hline Quinn $(1+17)$ & $\begin{array}{l}\text { Probabllity in } \\
\text { labor fnice. }\end{array}$ & $\begin{array}{l}\text { Gross curront hourly } \\
\text { wage, reported or im- } \\
\text { puted. }\end{array}$ & Eligibility dummy & Eligibility dumny & LRHS \\
\hline Reimers $(1977)$ & $\begin{array}{l}\text { Various including } \\
\text { probability retired } \\
\text { (self reportad). and } \\
\text { expected retirement } \\
\text { age. }\end{array}$ & $\begin{array}{l}\text { Gross reported current } \\
\text { hourly wage. }\end{array}$ & $\begin{array}{l}\text { Figibility dumny; } \\
\text { Current ss benefit. } \\
\text { if receiving ss. }\end{array}$ & $\begin{array}{l}\text { Eligibility dumbil: } \\
\text { Current gross dollar } \\
\text { benefit if receiving } \\
\text { pension. }\end{array}$ & NLS \\
\hline Sammartino $(1980)$ & $\begin{array}{l}\text { Probability ac- } \\
\text { cepted SS benefits. }\end{array}$ & $\begin{array}{l}\text { Gross reported annual } \\
\text { earnings in year before } \\
\text { survey. }\end{array}$ & $\begin{array}{l}\text { SSW as of age one year } \\
\text { before survey; SSDELTA } \\
\text { if retired now vs. next } \\
\text { year divided by benefit } \\
\text { foregone. }\end{array}$ & $\begin{array}{l}\text { Ejigibility dumin: } \\
\text { current gross doliar } \\
\text { benefit if receiving } \\
\text { pension. }\end{array}$ & LRHS \\
\hline
\end{tabular}

Notes to Table:

Columns $3-5$

PVapresent value of a stream of income, usually discounted for the probability of mortality.

PPW = Private pension wealth defined here as the present value (PV) of the stream of private pension benefits received if retirement occurs in a given year, until death.

SS=Social Secirity benefits.

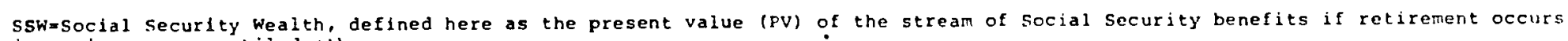
in a given year, until death.

PPDELTAdifference between PPF in a given year and pPiv if retirement is postponed until the next year.

SSDELTA=difference between SSW in a given year and sSw if retirement is postponed until the next year.

\section{Column 6}

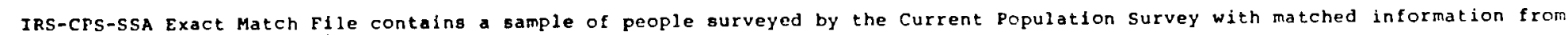
tax and Soclal Security files.

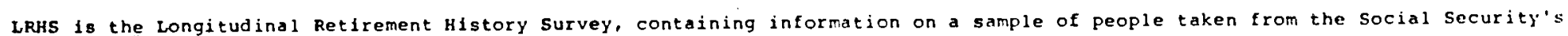
longltudinäl data files.

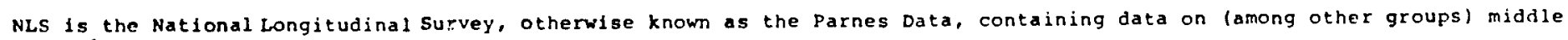
age nales.

PSID is the panel survey of income Dynamica containing information on several thousand families and individuals. 
It is clear then, that most writers use only current values of explanatory variables, rather than the theoretically appropriate streams of economic variables over the individual's remaining lifetime. The implication is that most empirical studies suffer from omitted variables and measurement error that may well bias results; implications of these problems should be examined by future researchers.

In order to address many of these issues, however, what is required is more and better data on the determinants of older workers' labor supply patterns than are now available. Existing surveys are deficient on several counts: they provide incomplete earnings data, they often contain too little information to determine Social Security benefits, and generally reveal next to nothing about the private pension plan rules confronted by employees. Some surveys are very sketchy indeed, reporting only whether a worker is eligible for a private pension or Social security rather than benefit levels and the structure of benefits as retirement is postponed. Others do more: for instance, the LRHS (see Table) can be used to compute Social Security benefits, but contains only sketchy private pension data. The Auto Workers' sample, on the other hand, may be used to derive benefits for different retirement ages but is silent on Social Security benefits to which workers are entitled. Most surveys contain no information on contribution schedules for private pension plans at all, and often do not report enough data to determine tax rates for individual workers. In part, these data problems account for the failure of empirical analysts to include all the 
relevant life cycle variables in empirical models. More complete survey information on workers' characteristics, and the structures of their earnings, pension and social security benefit streams would be invaluable.

B. Empirical Results

This section briefly summarizes what we have learned empirically about the effects of economic variables on older workers' labor supply. Of special interest are estimates of the impact of wages, pensions, and social security on retirement. ${ }^{1}$ As we have shown above, the life cycle context requires that the empirical analyst consider the theoretically important streams of wage and retirement income. Lacking this, we conclude at the outset that most of the empirical studies do no tell us much about the effects of wage and pension streams on retirement behavior. Therefore, this discussion

Isome of the studies discussed below, and others in the literature, develop empirical models of expected rather than actual labor supply patterns. For instance Reimers used the planned age of retirement as a dependent variable, as did Kotlikoff and $\mathrm{Hall}$ and Johnson. One problem with this is that many individuals report that they never will retire, yet empirical analysts sometimes make ad hoc assumptions about When retirement will actually take place. For instance, Kotlikoff assigns a retirement date of age 70 to those workers who state that they will never retire. However, a more funda-stantial problem is that planned retirement ages differ subconclually from many workers' actual retirement ages. Reimers behavior is loose. wrong." (p. 150). Most men predict their own retirement date error is not associated adition she finds that the prediction any significant way. A systematic and pension variables in making planned and. A systematic analysis of the factors while endeavour for future researchers. 
is confined to an overview of the partial information available. 1

Wages. Two kinds of wages influence retirement: the wage stream available on the worker's present job, and the wage stream available from some alternative employer. ${ }^{2}$

A parallel shift in the wage profile on the present job has both substitution and income effects and they work in opposite directions. An increase in the rate of wage growth has an additional intertemporal substitution effect, which, by itself, leads to postponed retirement. Thus, theory suggests that the present job's wage stream (including both wage level and wage growth) affects the age of retirement and that both of these effects are ambiguous in sign. Nonetheless, most analysts include current wage only and hypothesize that the effect of a higher current wage is later retirement. From theory, a higher wage available from an alternative employer encourages earlier retirement from the present job, since income and substitution effects work in the same direction for the decision to leave the principal employer; however, a higher wage from an alternative employer has an ambiguous effect

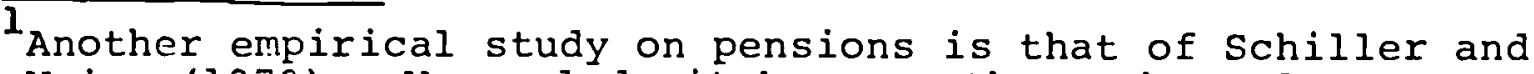
Weiss. (1979). We exclude it because the authors do not have available information on whether a worker: left to retire, whether he quit, or whether he was laid off or fired from his firm. Thus it is not informative on the effects of pensions on retirement.

${ }^{2}$ Presumably, net or disposable earnings are the relevant economic variable to use, after having substracted income and Social. Security taxes, and required pension contributions if any. However, net earnings have been used in few empirical studies.
} 
on the date of labor force withdrawal, since income and substitution effects work in opposite directions for the withdrawal decision. Most empirical analysts in the retirement field examine the effects of wages on the main job only. However, one study, by Gustman and steinmeier, exploits the longitudinal character of panel data to impute wages available in alternative jobs.

Turning to empirical results, we find:

Current Wages. Many studies discern no statistically significant effect of changes in the current wage: Cotterman, Hurd and Boskin, Quinn, and Reimers are in this group. Pellechio (1981) found that current wages had a statistically insignificant effect on retirement for all age groups but one, the over-65 (where the effect was negative). Gustman and Steinmeier do not report significance levels but state that the current wage measures they use had no impact on the probability of retirement. On the other hand several studies find that higher current wages deter retirement in a statistically significant way: studies reaching this conclusion are Boskin, Boskin and Hurd (with their gross wage measure), Burkhauser (1980), Burkhauser and Quinn, Clark and Johnson, Kotlikoff, Pellechio (1978), and Sammartino (1980). One study reaches the opposite conclusion, finding that higher current wages have a statistically significant effect inducing earlier retirement (Boskin and Hurd's net wage measure). ${ }^{l}$ Empirically, higher wage levels do not have a systematically strong impact

The study by Hall and Johnson finds that the current hourly wage was positively and significantly associated with planned earlier retirement. 
on retirement, though when statistically significant, higher wages result in later retirement.

Wage Streams. The disagreement over empirical results is reiterated in studies that develop a measure of the wage stream available to a worker on his present job. Burkhauser $(1976,1979)$ concludes that a worker has a significantly higher probability of continuing to work when the present value (PV) of the earnings stream rises. Gordon and Blinder agree with this conclusion but present no significance levels for their retirement results. Pellechio (1981) finds that higher PV of earnings has no effect on any groups, except males over age 65, where the effect is to reduce the likelihood of retirement. 1 Higher wage streams, when statistically significant, tend to encourage later retirement.

Wages from an Alternative Employer. The one study with clearcut answers on this issue is that by Gustman and Steinmeier. They find that a higher alternative wage has a statistically significant but small impact on behavior, by reducing the probability of withdrawing from the labor force. They do not present statistical significance levels for the effect of this wage measure on other behaviors, such as the probability of leaving the main job. ${ }^{2}$

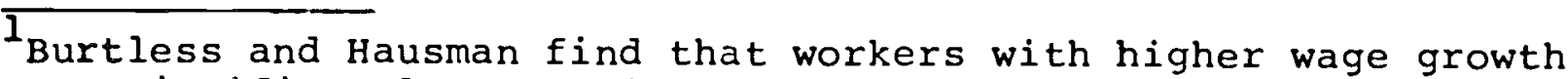
are significantly less likely to retire, but the fact that several wage variables are included interactively in their model makes it difficult to sort out a pure wage response.

2 Burtless and Hausman include a measure of earnings on an alternative job, via an imputed 1977 wage term; however the complex nonlinear and interactive ways in which it enters the model makes it difficult to sort out the impact on retirement.
} 
Contributions. Most of the analysts mentioned above utilize earnings measures that are gross of pension contributions. However, when a pension plan requires workers to contribute, the worker's net pay is less than his gross pay. In the model by Boskin and Hurd, current gross earnings are reduced by the Social security payroll tax, and they find that increases in the net wage significantly encourage retirement. 1 Pellechio (1981) finds a similar result with a different variable; he uses the PV of payroll taxes a worker has paid over his lifetime until the present as a separate regressor, and concludes that lower taxes significantly encourage retirement. ${ }^{2}$ only one empirical piece, Gordon and Blinder's, directly examines private pension contributions in a retirement model. 3 -However, these authors assume that benefits equal contributions for each individual, so that the separate impacts of pension benefit and cost streams are impossible to disentangle.

Social security. Theory suggests that a higher value of Social security benefits at first eligibility (age 62) induces earlier retirement, whereas the effect of a higher rate of increase in Social security benefits is ambiguous. Empiricai evidence, though limited, is available on each of these propositions. The results are inconclusive.

$\overline{I_{\text {Kotlikoff uses }}}$ yet a different earnings measure to evaluate the determinants of expected retirement ages. This is an annual labor earnings term which is net of income taxes but gross of both the employer's and employee's Social security contribution. The interpretation of such a wage measure is unclear, since retirement depends on a comparison of net returns from work vis a vis pension income.

2 This variable is tautologically endogenous because when a worker retires earlier, he pays payroll taxes for fewer years.

${ }^{3}$ The pension contribution variable is an imputed measure, since it was not reported in their data set. 
Some studies used data sets which measured only Social Security eligibility, not the dollar amount of benefits. Quinn, as well as Clark and Johnson, discern a positive relationship between own eligibility for social security and retirement. This finding that social security eligibility is associated with earlier retirement is what theory would predict. A second study that measured Social Security eligibility finds just the opposite ---Reimers reports a negative effect of Social security eligibility on the probability of retirement. ${ }^{1}$

Other authors utilize measures of dollar benefits for which the individual is currently eligible but are not able to measure the streams of Social security benefits. These results are in disagreement too: the studies by Boskin, Boskin and Hurd, and Pellechio (1981) find that higher current social Security benefits significantly encourage retirement, whereas Reimers and Kotlikoff find that higher benefit levels have no impact on retirement. 2

Following in Feldstein's footsteps, several researchers develop a measure of the present value of social security benefits (SSW) over the remainder of the individual's lifetime. Typically researchers compute only one value of SSW as of the date of the survey, or some other date. Pellechio $(1978,81)$ uses such a measure and finds that SSW significantly encourages the probability of being retired. This conclusion is reiterated

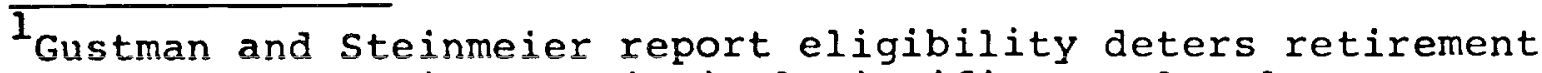
but do not provide statistical significance levels.

2 The variables representing levels of social security benefits used by Burtless and Hausman are not statistically significant, though complex interaction terms make intepretation difficult. 
in Burkhauser (1980), and Hurd and Boskin. ${ }^{1}$ However, Hamermesh and Clark and Johnson reach the opposite conclusion: in these studies, higher levels of own social security wealth significantly deter retirement. No significant impact is discerned by Burkhauser and Quinn, Cotterman, Kotlikoff and Sammartino (1980).

Other authors go further in incorporating measures of Social Security benefits streams available to a worker should he postpone retirement. Some authors find no effect: for instance Sammartino (1980) computes the difference in SSW if the worker retires one year later, but finds that it does not significantly influence retirement. The same variable significantly encourages retirement in Burkhauser and Quinn, but deters retirement in Pellechio's (1981) study.

In summary, our literature review indicates that retirement is affected ambiguously by social security eligibility, by current dollar benefits, by social security wealth, and by the change in social security wealth. No study includes values of Social security benefits available at all possible retirement dātes. Clearly, no empirical conclusion can be drawn about the effects of social security on retirement.

Private Pensions. Theory suggest that a higher private pension benefit level in the year of first eligibility induces earlier retirement, whereas the effect of a higher

IGordon and Blinder's finding is consistent with these four but no statistical significance levels are given. 
rate of increase in private pension benefits is ambiguous. Evaluating the effects of pensions in empirical data has been difficult, however, since information on the structures of private pensions is very poor. Data sets with national coverage, such as the NLS and the LRHS (see Table) seldom have information on pension levels, and never report how pension benefits would change if the worker postponed retirement. Only the Auto Workers' sample used by Burkhauser provided the requisite information.

Because of such data limitations, researchers have often been limited to constructing eligibility aummies reflecting private pension coverage. ${ }^{1}$ Quinn's research concludes that people eligible for private pensions are significantly more likely to leave the labor force than those without pensions. This conclusion is reiterated by Gordon and Blinder, as well as by Gustman and Steinmeier, though neither study reports significance levels. Clark and Johnson find that males react as expected (eligibility is positiveiy associated with retirement), but females who are covered tend to remain in the labor force. 2 On the other hand there is room for diversity of opinion here too: the studies by Reimers, Burkhauser and Quinn, and Kotlikoff, report that people with pensions are significantly less likely to leave the labor force. Sammartino (1980) finds

$\overline{l_{\text {Many empirical }}}$ studies omit private pension variables altogether; see Table.

${ }^{2}$ The authors suggest that women covered by private pensions may be more career oriented than women without this coverage, which might explain their lower retirement probability. 
no significant effect of private pension coverage. ${ }^{1}$

Three studies, by Boskin, Burtless and Hausman, Sammartino (1980) examine the impact of current pension benefit levels. Boskin reports that higher benefit levels are significantly related to the probability of being retired rather than working; the latter two studies however, find no significant impact on retirement.

A few recent studies develop measures of private pension wealth, analogous to the SSW variable described above. 2 Clark and Johnson, and Hamermesh, find that higher private pension wealth is positively and significantly associated $\because$. with retirement, among males. For females, however, clark and Johnson discover that higher PPW significantly lowers the probability of retirement. An equivalent measure in Cotterman's work, and that of Burkhauser and Quinn, is found to have no effect on retirement. 3

Three empirical analyses evaluate the PDV of the difference between the private pension one would receive if one retired now, and the annual pension that could be received if retirement were postponed a year. Burkhauser $(1976,1979)$ reports that the Auto Workers in his sample retired significantly earlier

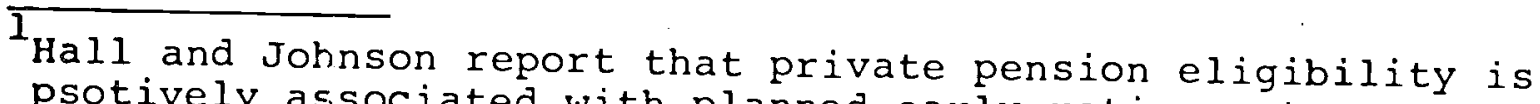
psotively associated with planned early retirement.

2 of course the relevant economic variable is after-tax private pension amounts, though only one study corrected for taxes (Burkhauser, 1979).

3 Hurd and Boskin include pension wealth in a nonearned income variable and find a negative effect on retirement. However, the interpretation of this term is difficult since the effect of pension wealth is confounded with other nonearned income
sources. 
when they faced a larger decline in their private pension wealth as retirement was postponed. Burkhauser and Quinn reach the same conclusion using the LRHS data set.

On balance then, the evidence (when significant) is reasonably consistent with theory: current eligibility for a private pension has an ambiguous effect on retirement, but higher current benefit levels tend to encourage retirement. However, even the best empirical studies have considered the patterns of pension benefits only at two possible retirement ages. No one has modeled the entire stream of pension opportunities available to the older worker. Better data on private pension levels and rules are required to derive better estimates of the effects of pensions on retirement.

C. Sumnary

In sum, our review of the empirjcal literature suggests that:

(1) Higher wages from the principal employer, when statistically significant, are associated with later retirement.

(2) Higher wages on an alternate job have been considered in only one study; they have a small negative effect on retirement.

(3) Contributions to private pensions have not received empirical attention independent of benefit streams.

- (4) Contributions to Social Security have been considered independently of Social security benefits in one study, in which they were found to deter retirement. 
(5) Higher Social Security benefits have an amgibuous effect on retirement.

(6) Higher private pension benefits tend to encourage retirement though the evidence is somewhat mixed.

Existing empirical studies have not incorporated even the majority of the relevant wage and pension variables determining older workers' life cycle labor supply and retirement patterns, and hence are subject to serious specification errors. The links between life cycle theory and empirical analysis are weak. Data limitations are severe. Until these deficiencies are remedied, the empirical effects of pensions and earnings on retirement will remain uncertain. 


\section{References}

Abeles, Ronald P. and Riley, Matilda White. "A Life-Course Perspective on the Later Years of Life: Some Implications for Research." Social Science Research Council Annual Report, 1976-1977.

BenPorath, Yoram. "The Production of Human Capital and the Life Cycle of Earnings." Journal of Political Economy, August, 1967.

Blinder, Alan S., Gordon, Roger H., and Wise, Donald E. "Reconsidering the Work Disincentive Effects of Social Security." National Tax Journal, forthcoming.

BIinder, Alan S. and Weiss, Yoram. "Human Capital and Labor Supply: A Synthesis." Journal of Political Economy, June, 1976 .

Boskin, Michael J. "Social Security and Retirement Decisions." Economic Inquiry, January 1977.

Boskin, Michael J. and Hurd, Michael D. "The Effect of Social Security on Early Retirement." Journal of Public Economics, December 1978.

Bulow, Jeremy I. "Early Retirement Pension Benefits." NBER Working Paper No. 654, April 1981.

Burbidge, J. B. and Robb, A. L. "Pensions and Retirement Behavior." Canadian Journal of Economics, August, 1980.

Burkhauser, Richard V. "The Early Acceptance of Social Security: An Asset Maximization Approach." Industrial and Labor Relations Review, July, 1980.

Burkhauser, Richard V. "The Early Pension Decision and Its Effect on Exit from the Labor Market." Ph.D. dissertation, University of Chicago, 1976.

Burkhauser, Richard V. "The Pension Acceptance Decision of Older Workers." Journal of Human Resources, 1979.

Burkhauser, Richard V. and Quinn, Joseph. "Mandatory Retirement study, Part I." Task Completion Report Submitted by the Urban Institute, June 1980.

Burkhauser, Richard V. and Warlick, Jennifer L. "Disentangling the Annuity from the Redistributive Aspects of Social Security." Institute for Research on Poverty Discussion Paper 562-79, University of Wisconsin, November 1979.

Burtless, Gary and Hausman, Jerry. "Individual Retirement Decisions Under An Employer Provided Pension Plan and Social Security." Unpublished paper, November 1980. 


\section{References Continued}

Campbell, Colin D. and Campbell, Rosemary G. "Conflicting Views on the Effect of Old-Age and Survivors' Insurance on Retirement." Economic Inguiry, September 1976.

Clark, Robert L. ed. Retirement Policy in an Aging Society. Duke University press, Durham, 1980.

Clark, Robert L. and Johnson, Thomas. "Retirement in the Dual Career Family." Final Report SSA Grant No. 10-P-90543-4-02, June 1980.

Clark, Robert, Kreps, Juanita, and Spengler, Joseph. "Economics of Aging: A Survey." Journal of Economic Literature. September 1978 .

Clark, Robert L. and McDermed, Ann Archibald. "Inflation, Pension Benefits and Retirement." Unpublished manuscript prepared at North Carolina State University, no date.

Clark, Robert $L$. and Spengler, Joseph $j$. The Economics of Individual and Population Aging. Cambridge University Press, 1980 .

Cotterman, Rotert. A Theoretical and Fmpirical Analysis of the Labor Supply of "Older" males. Unpublished Ph.D. Dissertation, The University of Chicago, March, 1978.

Crawford, Vincent P. and Lilien, David M. "Social Security and the Retirement Decision." Quarterly Journal of Economics, August 1981 .

Diamond, Peter, and Mirrlees, J. A. "A Model of Social Insurance with Variable Retirement." Journal of Public Economics, 1981 .

Driffill, E. J. "Life Cycles with Terminal Retirement." International Economic Review, February, 1980.

Eaton, Jonathan and Rosen, Harvey S. "Pensions, Agency, and the Structure of Executive Compensation." NBER Pensions Program, June 1981.

Feldstein, Martin. "Social Security, Induced Retirement, and Aggregate Capital Accumulation." Journal of Political Economy, 1974.

Fields, Gary S. and Mitchell, Olivia S. "Pensions and the Optimal Age of Retirement." Department of Labor Economics Working Paper No. 27, Cornell University, March 1981.

Ghez, Gilbert R. and Becker, Gary S. The Allocation of Time and Goods over the Life Cycle. New York: Columbia University Press, 1975. 


\section{References Continued}

Gordon, Roger H. and Blinder, Alan S. "Market Wages, Reservation Wages, and Retirement Decisions." Journal of Public Economics, Vol. 14, No. 2, Oct. 1980.

Gotz, Glenn A. and McCall, John J. "Estimating Military Personnel Retention Rates: Theory and Statistical Method." RAND Project Air Force Report, R-2541-AF, June 1980.

Gustman, Alan and Steinmeier, Thomas. "Partial Retirement and the Analysis of Retirement Behavior." Unpublished paper, Dartmouth College, April 1981.

Hagens, John B. "Social Security as Retirement Insurance." Paper Presented at the Econometric Society Meetings, Atlanta, December 1979.

Hall, Arden and Johnson, Terry R. "The Determinants of Planned Retirement Age." Industrial and Labor Relations Review, January 1980.

Hamermesh, Daniel S. "A General Empirical Model of LifeCycle Effects in Consumption and Retirement Decisions." Unpublished paper, Michigan State University, June 1981.

Heckman, James J. "A Life Cycle Model of Earnings, Learning and Consumption." Journal of Political Economy. August 1976.

Hemming, R. C. L. "The Effect of State and Private Pensions on Retirement Behavior and Personal Capital Accumulation." Review of Economic Studies, Vol. 44, No. 1, February 1977.

Honig, Margorie and Hanoch, Giora. "Age, Cohort, and Period Effects In a General Model of Labor Market Behavior of older Persons." Mimeo, no date.

Hu, Sheng Cheng. "Social Security, the Supply of Labor, and Capital Accumulation." American Economic Review. June 1979.

Hurd, Michael D. and Boskin, Michael J. "The Effect of Social Security on Retirement." NBER Working Paper No. 659, April 1981.

Kotlikoff, Laurence J. "Testing the Theory of Social Security and Life Cycle Accumulation." American Economic Review. June 1979.

Iazear, Edward P. "Severance Pay, Pensions, Mobility, and the Efficiency of Work Incentives." Preliminary Draft, June 1981.

Lazear, Edward P. "Why is There Mandatory Retirement?" Journal of Political Economy. November/December 1979 . 


\section{References Continued}

MacDonald, Glenn M. and Carliner, Geoffrey. "A Theory of Optimal Retirement." Unpublished paper, University of Western Ontario, October 1980.

Mitchell, Olivia S. "Fringe Benefits and the Costs of Changing Jobs." NBER Conference Paper No. 96, Feburary 1981.

Munnell, Alicia. "The Impact of Inflation on Private Pensions." New England Economic Review. March/April, 1979.

Pellechio, Anthony J. "The Effect of Social security on Retirement." NBER Working Paper No. 260, July 1978.

Pellechio, Anthony J. "Social Security and the Decision to Retire." Unpublished paper, University of Rochester, June 1981.

President's Commission on Pension Policy. Coming of Age: Toward a National Retirement Income Policy. Feburary 1981.

Quinn, Joseph J. "Microeconomic Determinants of Early Retirement: A Cross-Sectional View of White Married Men." Journal of Human Resources, Summer 1977.

Reimers, Cordelia K. W. "The Timing of Retirement of American Men." Unpublished Ph.D. Dissertation, Columbia University, 1977.

Robertson, James $\%$. "Social Security and Pensions; The Effects on Savings and Retirement: A Survey of the Literature." Urban Institute Working Paper No. 1286-80, Feburary 1980.

Ryder, Harl, E., Stafford, Frank P., and Stephan, Paula E. "Labor, Leisure, and Training Over the Life Cycle," International Economic Review, October 1976.

Sammartino, Frank. "A Model of the Retirement Decision." Paper presented at the Labor Workshop, University of Wisconsin, Madison, February 1978.

Sammartino, Frank. "The Timing of Social Security Acceptance by Older Men." Unpublished paper, Office of Income Security Policy, Department of Health and Human Services, revised september 1980.

Schiller, Bradley, and Weiss, Randall. "The Impact of Private Pensions on Firm Attachement." Review of Economics and Statistics, August, 1979.

Schiller, Bradley and Weiss, Randall, "Pensions and Wages: A Test for Equalizing Differences." Review of Economics and Statistics, Vol. 62, No. 4, November 1980 . 


\section{References Continued}

Schulz, James $\mathrm{H}$. The Economics of Aging. Wadsworth Inc., Belmont, $C A 1 \overline{976 .}$

Sheshinksi, Eytan. "A Model of Social Security and Retirement Decisions." Journal of Public Economics, December 1978.

Smith, Robert. "Compensating Differentials for Pension Underfunding in the Public Sector." Review of Economics and statistics, forthcoming.

Taubman, Paul. "Pensions and Mortality." NBER Pensions Program, June 1981.

Tepper, Irwin. "Pension Fund Asset Allocation." NBER Pensions Program Research Paper, June 1981.

Weiss, Yoram. "On the Optimal Pattern of Labor Supply." Economic Journal, December 1972.

Zabalza, Anthony, Pissarides, Christopher and Barton, M. "Social Security, and the Choice Between Full-Time Work, "Part-Time Work, and Retirement." Journal of Public Economics, Vol. 14, No. 3. October 1980. 